\title{
Nutrient deficiency and effects of various nutrition technologies on crop health
}

\author{
Dalma Rácz - László Radócz \\ Department of Plant Protection, Faculty of Agriculture, University of Debrecen, 4032 Debrecen, \\ Böszörményi út 138 \\ racz.dalma@agr.unideb.hu
}

\begin{abstract}
SUMMARY
The impacts of climate change on crop production are increasingly noticeable. Extreme weather conditions - such as devastating droughts, which occur more often - have serious effects on crop conditions, thus damaging their defence ability against pathogens and pests. Therefore, in order to achieve high-quality and high yielding crops, it is urgent to elaborate new technologies that improve general condition of crops and prevent development of nutrient diseases. Those crops which suffer from the lack of certain nutrients are more sensitive and their tolerance against diseases are decreased. Nitrogen - as the most influencing macronutrient in yield - is also essential in maintaining crop health. Nevertheless, due to the complicated processes in soil (such as leaching, denitrification), the utilization of nitrogen is not nearly complete, therefore nitrogen stabilizers may be needed to maximize this factor. The use of these stabilizers can be promising where plants with high nitrogen content are grown, although further experiments are needed in which impacts of nitrogen stabilizers on crop protection aspects are examined as well, since there is a close correlation between exaggerated nitrogen fertilizing and sensitivity to pests. During my research I am going to examine the combined effect of foliar fertilizer and nitrogen stabilizer on crop health. Furthermore, my goal is to find clear correlation between pathogens and the different technological variants of nutrition.
\end{abstract}

Keywords: plant nutrition, nutrient deficiency, nitrogen stabilizer, nitrapyrin, condition of plants

\section{INTRODUCTION}

For the purpose of the healthy development of crops, it is necessary for all nutrients to be in balance. The appropriate condition of crops can be ensured by optimum and satisfactory supply of nutrients, since the ability of defense against biotic and abiotic stress is improved. For instance, it has been known for a long time that optimal P-and $\mathrm{K}$ supply can strengthen the health of crops (Perrenoud, 1990). Although it is not possible to defend diseases with only nutrition itself, however, professional supply of nutrients is elemental part of integrated crop protection in order to prevent and treat diseases (Reuveni and Reuveni, 1998).

Basically, development of nutrient deficiency is due to the lack of each nutrients of cells. In case of absence of essential elements -such as $\mathrm{N}, \mathrm{S}, \mathrm{P}, \mathrm{Mg}$, $\mathrm{Ca}$ (essential cell components), the development and growth of the crops can be disturbed (Table 1; Füleky and Sárdi, 2014).

In general, the observation one-year, fast-growing and plants which require many nutrients show the symptoms of nutrient deficiency often, therefore, it is not surprising that nutrient deficiency was determined in vegetables at first (for instance, Ca-deficient tomatoes) (Bergmann, 1979).

Table 1

Essential components of plant cell

\begin{tabular}{cc}
\hline Nutrient & Function in plants \\
\hline $\mathrm{N}, \mathrm{S}$ & amino acids \\
$\mathrm{P}$ & nucleotides \\
$\mathrm{Mg}$ & chlorophyll \\
$\mathrm{Ca}$ & pectin \\
$\mathrm{Fe}, \mathrm{Cu}, \mathrm{Zn}$ & enzymes \\
\hline
\end{tabular}

There is a close correlation between the mobility of nutrients and the development of deficiency symptoms. Nutrient deficiency in young plants (initial growth) may even lead to destruction, though, in an older stage of development, crops are able to mobilize the nutrients from older part to the younger, still developing parts. For this reason, recognizing which part of the plant shows deficiency symptoms is very important. In the case of $\mathrm{N}-, \mathrm{P}-, \mathrm{K}-, \mathrm{Mg}$ elements (mobile nutrients) symptoms of nutrient deficiency are shown in older plant parts, while in case of lowmobility nutrients (Fe, S, B, Ca etc.) younger parts show the signs of the absence of each nutrient (Figure 1; Bergmann, 1979).

Symptoms of micronutrient deficiency are observed on younger leaves, since most of the micronutrients are not able to translocate. Nevertheless, Mo is an exception because it's absence may occasionally appear on the whole plant (Gupta et al., 2008).

The development of micronutrient deficiency may have several reasons. Little micronutrient content resulting from the geological conditions of the soil, disadvantageous $\mathrm{pH}$ of the soil solution, one-sided and high-dose macronutrient nutrient supply, inappropriate moisture condition of soil and it's drying - these are all potential reasons (Szentmihályi et al., 1987).

In general, uptake of micronutrients is influenced by the following factors:

1) $\mathrm{pH}$ of the soil solution

2) abiotic stress factors (for instance drought)

3) Interaction between minerals (synergism, antagonism) 


\section{Figure 1: Connection between mobility of nutrients and deficiency symptoms}

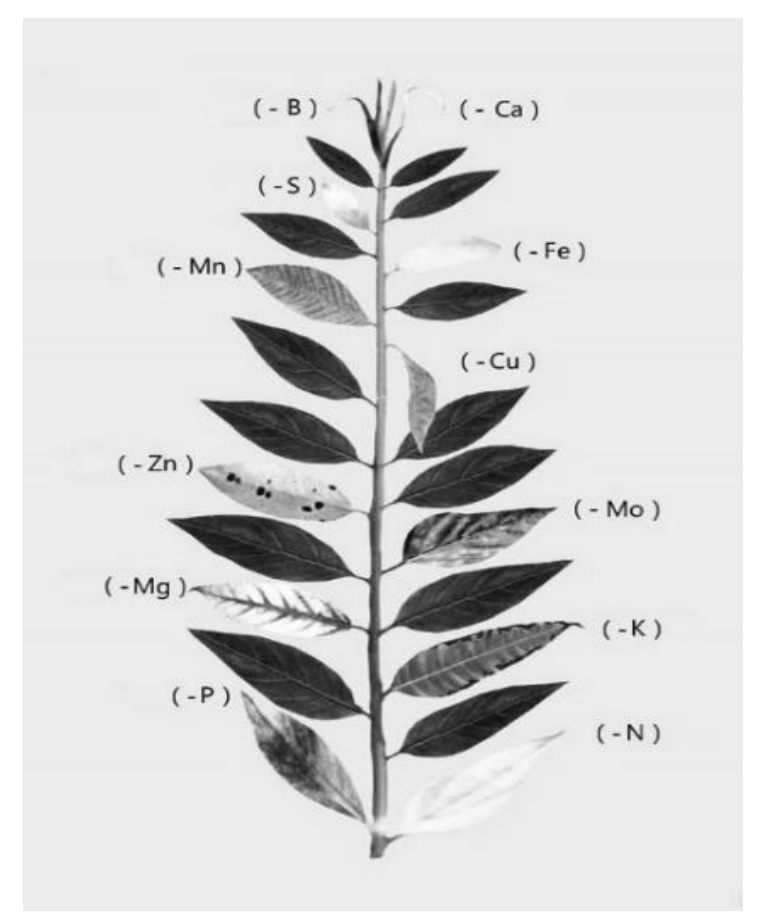

Notation: This figure shows that deficiency symptoms of mobile nutrients are observed in old leaf, while immobile nutrients are observes in young leaf at first.

Source: Fertilizer Nutrient Deficiency Disease State of Leaf Plants in: www.acefertilizer.com

Soil $\mathrm{pH}$ is one of the most determining factors which influences micronutrient uptake. With the increase of $\mathrm{pH}$, the ability of micronutrient uptake deteriorates - except for Mo (Gupta et al., 2008), which explains the fact that, due to the low solubility in calcic soils, micronutrient deficiency is frequent (Figure 2; Sárdi, 2011).

Figure 2: The role of $\mathbf{p H}$ in nutrient mobility

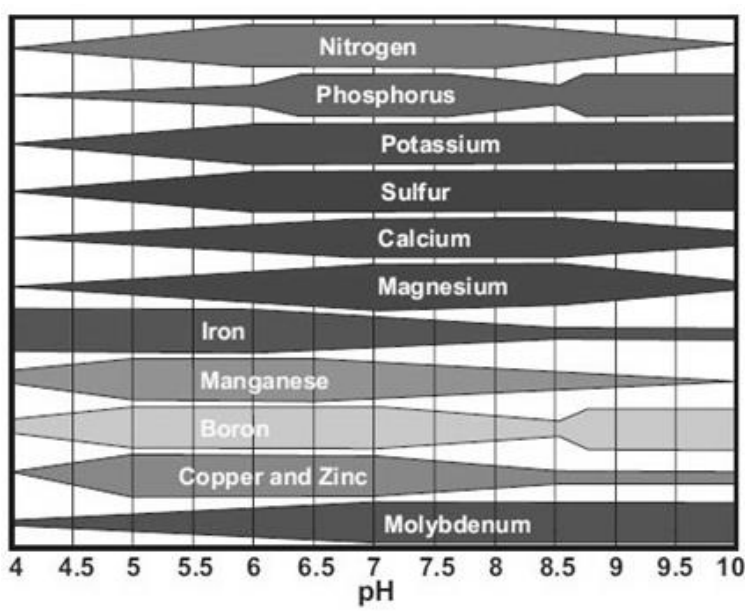

Source: www.moyerslawnservice.com
The mobility and utilization of each nutrient is strongly influenced by interaction between ions. These ion ratios show their effect through synergism and antagonism. Antagonism is expressed when predominance of an ion can limit or reduce the absorption of an other element. Ion antagonism exists between the $\mathrm{K}^{+},, \mathrm{Ca}^{2+-}, \mathrm{Mg}^{2+}-, \mathrm{NH}_{4}{ }^{+}$ions (Table 2; Figure 3; Loch and Nosticzius, 2004).

Table 2

Table of antagonistic elements

\begin{tabular}{cc}
\hline Excess Element & Nutrient(s) affected \\
\hline Nitrogen & Potassium, Calcium \\
Potassium & Nitrogen, Calcium, Magnesium \\
Phosphorus & Zinc, Iron, Copper \\
Calcium & Boron. Magnesium, Phosphorus \\
Magnesium & Calcium, Potassium \\
Iron & Manganese \\
Manganese & Iron, Molybdenum, Magnesium \\
Copper & Molybdenum, Iron, Manganese, Zinc \\
Zinc & Iron, Manganese \\
Molybdenum & Copper, Iron \\
Sodium & Potassium, Calcium, Magnesium \\
Aluminium & Phosphorus \\
Ammonium ion & Calcium, Copper \\
Sulfur & Molybdenum \\
\hline
\end{tabular}

Source: Nutrient Antagonism: Too Much of a Good Thing in: www.occnewspaper.com

Synergism is a positive correlation in which an element helps an other's mobility. For example, this exists between $\mathrm{N}$ and $\mathrm{P}$, or $\mathrm{Mg}$ and $\mathrm{B}$ nutrients (Loch and Nosticzius, 2004).

As a result of extreme droughts, the use of foliar fertilizer is becoming increasingly reasonable, since nutrition uptake through the roots is more difficult in dry soil conditions. In addition, this method requires enormous energy investment from crops. Supplying nutrients with foliar fertilizers can ensure the required micro-meso-and even macronutrients for crops. In this way, utilization of nutrients is safer and more preferential (Fernández and Eichert, 2009), moreover, this technology allows to apply several additional materials (such as activators, enzymes). Prevention and exploration of crop's nutrient deficiency (appropriate nutrition technology) has become even more remarkable in plant protection. Micro-element foliar fertilizers are primarily important for horticultural plants, although, due to the higher demand for improving and increasing yields, it is reasonable to point out that this form of micronutrient supply can also be used on field crops (Prcznik, 1976).

There are complex foliar fertilizers are available for farmers which are often complemented with biostimulants. In general, these components -which are made of natural or synthetic materials - stimulate the ability of defense against abiotic- and biotic stress through improving crop's condition and health (du Jardin, 2015). 


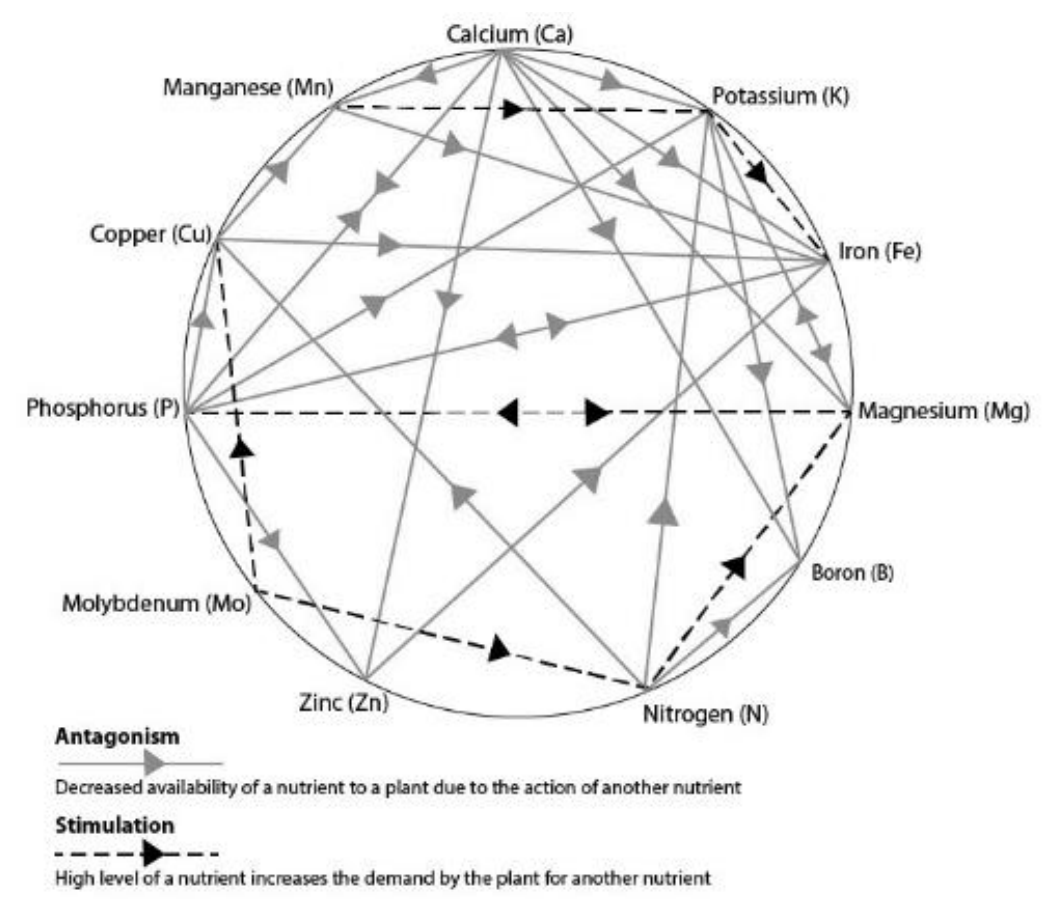

Source: Nutrient interactions in the soil in: www.jseco.co.uk/services/facts-advice/

Nitrogen - as the most influencing macronutrient in yield - is also essential in improving crop health. Nevertheless, due to the complicated processes in soil (such as leaching, denitrification) the utilization of nitrogen is nearly not complete. Crops can access nitrogen in its mineral form $\left(\mathrm{NH}_{4}{ }^{+}, \mathrm{NO}_{3}{ }^{-}\right)$(Füleky and Sárdi, 2014). Since $\mathrm{NO}_{3}^{-}$is a negatively charged anion, it cannot strongly bind to soil colloids which are negatively charged as well. For this reason, $\mathrm{NO}_{3}$ has the tendency to moving and leaching. However, $\mathrm{NH}_{4}{ }^{+}$is a positively charged cation which can be strongly adsorbed on the surface of the negatively charged soil colloids; therefore, this form of nitrogen is favourable for crops, in additional it is environmental friendly. Due to nitrate ion's properties it contributes to environment pollution which is manifested in leaching in to ground water and denitrification. Furthermore, nitrogen- and dinitrogenoxides - as greenhouse gases - are emitted through the denitrification, which contribute to the global warming (Futó et al., 2016). From these two gaseous nitrogen forms the dinitrogen-oxide $\left(\mathrm{N}_{2} \mathrm{O}\right)$ causes even higher risk than $\mathrm{CO}_{2}$, since $\mathrm{N}_{2} \mathrm{O}$ stimulate greenhouse effect 300 times stronger (Papp, 2014). From all of this it is evident that growing crops haven't got the ability to utilize all of the nitrogen that farmers have applied to the fields. Therefore, achieving potentially maximum yields is not possible. Numerous efforts have been made in order to reduce emissions of these gases and to increase the utilization of the applied nitrogen. Using different types of nitrogen stabilizers seems promising solution, which aims to maximize the applied nitrogen fertilizer through slowing metabolism of nitrogen converter bacteria in soil (thus reducing nitrate formation). With this method crops condition can be improved, thus higher yields can be achieved with lower environmental load (Papp, 2014).

Nitrapyrin - as a nitrification inhibitor - has been used for long time among farmers, especially in areas where crops with high nitrogen content (cereals, corn, oilseed rape) are grown. Nitrapyrin has effect only on Nitrosomonas bacteria species, which are responsible for converting ammonium ion to nitrite (CampbellAleem, 1965).

Through the inhibition of bacterial life we can achieve that ammonium ion is available for longer time for crops, therefore, there is a chance to reduce nitrogen loss. Moreover, with this method the environmental pollution to the groundwater and air is also moderated by reducing nitrate ion concentration.

Although the effectiveness of nitrapyrin is proved, we still do not know enough about influencing factors. According the heterogeneity of the soils, the question may be arisen, that if nitrapyrin - which selectively affects Nitrosomonas bacteria species - application is solved by using precision technology. Therefore, it is assumed that the composition of bacterial species in the soil is heterogeneous which suggests that nitrapyrin should be applied where these Nitrosmonas bacteria species are found.

\section{MATERIAL AND METHODS}

During my $\mathrm{PhD}$ research nutrient deficiency of crops with high nitrogen content (maize, oilseed rape, wheat) and the resulting effects on plant protection problems are going to be examined. Furthermore, 
combined effects of various nutrition technologies (foliar fertilizer, nitrogen stabilizer) on crops defense ability against pathogens, pests and weeds are also being examined.

Examinations are expected to begin in spring of 2019 and they will be set up in 4 repetitions:

1. Traditional control

2. plot with nitrapyrin treatment

3. plot with nitrapyrin and foliar fertilizer

As it was described, best results are expected from combined treatment of foliar fertilizer and nitrogen stabilizer in improving natural ability of defense against pathogens. In other words, their combined effect will probably provide the healthiest and freest of infections crops, since both nitrapyrin - which results nitrogen uptake by crops higher concentration - and both foliar fertilizer with microelements and bio stimulators have advantageous effects on improving crop health and enchanting yield.

Between plot with nitrapyrin and control significant differences are expected, since nitrapyrin can increasing yield production (on average +6 $10 \%)$. On the other hand, I would like to examine the presence of nitrogen forms in soil which crops can uptake in surface and deeper layers as well. During research, possibilities of precision application of nitrapyrin due to the fact, that nitrapyrin only effects Nitrosomonas bacteria species. However, considering the heterogeneity of soil conditions - therefore diversity of bacteria species in soil - it would be advisable to only treat soils in where these target bacteria species are contained.

During research the planned main examinations are the following:

- Exploration of hidden deficiency diseases of the most important crops by using leaf analysis and soil testing (updating the supply levels of crops)

- Examination of application possibilities and combined effects of foliar fertilizer and nitrapyrin (nitrogen stabilizer)

- Detailed plant protection problem diagnosis of each crops which suffer from hidden nutrient deficiency.

- Examine the possibilities of precision application of nitrapyrin

\section{RESULTS AND DISCUSSION}

According to the literatures, especially maize is particularly sensitive to the lack of zinc nutrient, therefore during the examination the typical symptoms are expected. If the experimental soil contains high level of Ca nutrient (lime soil), there is a chance to prove antagonism between $\mathrm{P}$ and $\mathrm{Zn}$ elements with the help of leaf analysis. Among nutrients requirement of oilseed rape, the role of sulfur, boron, manganese and magnesium microelements is outstanding, in wheat the lack of copper micronutrient can be expected.

During my research, I also try to find out how the condition of nutrient deficiency crops differs from the treated (micronutrient supply) ones. With other words, the connection between intensity of infections and different nutrient supply of crops are going to be researched. Elek and Kádár (1980) have already had experiments in wheat and corn in order to respond this question. The intensity of powdery mildew (Blumeria graminis f.sp. tritici) and corn smut (Ustilago maydis) increased in direct proportion with the amount of $\mathrm{N}$ fertilization. It was also obvious that the improvement of $\mathrm{P}$ supply and decrease of N/P ratio significantly reduced the incidence of diseases. The intensity of gibberellic stalk rot (Gibberella zeae) in corn can be correlated with the lack of $\mathrm{Zn}$ micronutrient due to the one-sided, overdosed P-fertilization. On those plots, where the content of zinc decreased to about $20 \mathrm{ppm}$ and the ratio of $\mathrm{P} / \mathrm{Zn}$ was above 200 , the intensity of disease has reached, or in some cases exceeded $50 \%$ (Elek and Kádár, 1980).

From all of these I conclude that crops which suffer from nutrient supply higher presence of diseases can be expected.

I expect that treatment with nitrapyrin results higher yield. Furthermore, measuring the distribution of nitrogen forms in the soil I expect higher ammonium ion concentration in surface even months later compare and lower nitrate ion concentration compare to the untreated ones. With this results the environment protective effect of nitrapyrin can be justified.

\section{CONCLUSIONS}

The health condition of crops - natural ability of defense against diseases - can be improved with optimal nutrient supply. Due to the extreme weather conditions -which cause stress for crops - it is even more important and urgent challenge to apply reasonable and special nutrition technologies in everyday practice for crops in order to prevent or reduce the presence of diseases, since with this method we can not only avoid hidden nutrient deficiencies but also significantly improve crop productivity.

\section{REFERENCES}

Bergmann, W. (1979): Termesztett növények táplálkozási zavarainak előfordulása és felismerése. Budapest, Mezőgazdasági Kiadó
Campbell, N. E. R.-Aleem, M. I. H. (1965): The effect of 2chloro,6-(trichloromethyl) pyridine on the chemoautotrophic metabolism of nitrifying bacteria. I. Ammonia and 
hydroxylamine oxidation by Nitrosomonas Antonie van Leeuwenhoek J. Microbiol. Serol. 31:124-136.

du Jardin, P. (2015): Plant biostimulants: definition, concept, main categories and regulation. Sci. Hortic. 196:3-14.

Elek, É.-Kádár, I. (1980): Állókultúrák és szántóföldi növények mintavételi módszere. Budapest, MÉM Növényvédelmi és Agrokémiai Központ

Fernández, V.-Eichert, T. (2009): Uptake of hydrophilic solutes through plant leaves: current state of knowledge and perspectives of foliar fertilization. Critical Reviews in Plant Sciences 28:36-68.

Füleky, Gy.-Sárdi, K. (2014): Tápanyag-gazdálkodás mezőgazdasági mérnököknek. Budapest, Mezőgazda Kiadó

Futó, Z.-Bence, G.-Holes, A.-Surányi, Sz.-Papp, Z. (2016) Korszerü növénytáplálás a növénytermesztésben. Szent István Egyetem, Gazdasági, Agrár- És Egészségtudományi Kar, Tessedik Campus - Szent István Egyetem, Mezőgazdasági És Környezettudományi Kar - Dow AgroSciences Hungary Kft

Gupta, U. C.-Kening, W. U.-Siyuan, L. (2008): Micronutrients in soils, crops, and livestock. Earth Science Frontiers, 15(5):110125 .
Loch, J.-Nosticzius, Á. (2004): Agrokémia és növényvédelmi kémia. Budapest, Mezőgazda kiadó

Papp, Z. (2014): The role and impact of N-Lock (N-stabilizer) to the utilization of $\mathrm{N}$ in the main arable crops. 62:51-55.

Pecznik, J. (1976): A fotoszintézis és környezeti ténezői. Levéltrágyázás. Budapest, Mezőgazdasági Kiadó. 5-7. 163.

Perrenoud, S. (1990): Potassium and Plant Health. Bern, International Potash Institute

Reuveni, R.-Reuveni, M. (1998): Foliar-fertilizer therapy - a concept in integrated pest management. Crop Protection, 17(2):111-118

Sárdi, K. (2011): Tápanyaggazdálkodás. Debreceni Egyetem, Nyugat-Magyarországi Egyetem, Pannon Egyetem

Szabó, S. A.-Regiusné, M. Á.-Győri, D.-Szentmihályi, S. (1987): Mikroelemek a mezőgazdaságban I. - Esszenciális mikroelemek. Budapest, Mezőgazdasági Kiadó 
